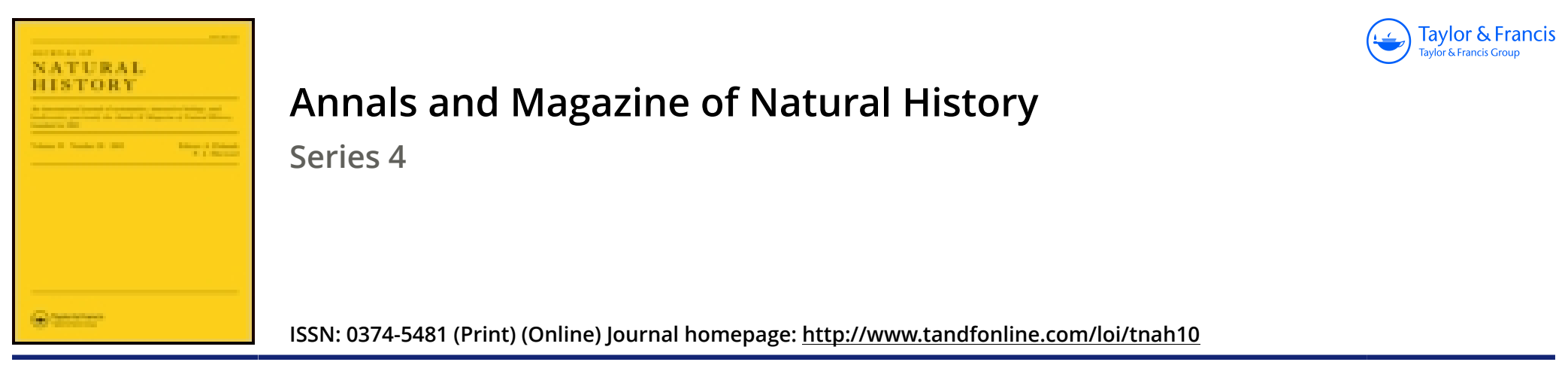

\title{
The habitat of Pelargopsis gigantea
}

\section{Dr. Adolf Bernard Meyer}

To cite this article: Dr. Adolf Bernard Meyer (1874) The habitat of Pelargopsis gigantea, Annals and Magazine of Natural History, 13:77, 401-402, DOI: 10.1080/00222937408680889

To link to this article: http://dx.doi.org/10.1080/00222937408680889

曲 Published online: 13 Oct 2009.

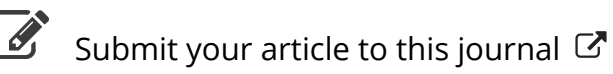

III Article views: 3

Q View related articles $₫$ 
Kuda (Rhinochoerus), received from Leyden under the name of Tapirus malayanus; and the Museum has recently received the skin of a much younger animal, which was brought to this country with the skin of an adult animal which is in the Musenm. They are both said to have come from Sumatra.

These two young skins differ considerably in the markings; and as I have lately observed the same thing in the American tapirs and figured them (P. Z. S. 1872, p. 489, t. xxi. \& xxii. and p. 624, t. xlv.), I have thought it desirable to describe the two specimens to draw attention to the differences, so as to learn if the young animals vary in this respect or indicate two species distinguished by the different colouring of the young.

Both specimens agree with the young West-Indian and the Peruvian tapirs in having their legs and feet with large, white, unequalsized spots.

The larger specimen received from Leyden is more or less bleached to a brown colour. The back and sides are marked with elongate white spots placed in lines; but the spots frequently do not meetthe ends being above or below the spots behind them, and often produced beyond them. Above and below the upper lateral stripe there is also a series of very small white elongated spots on the hinder part of one side ; and on the other side there are some small spots in a similar place near the shoulder. The two streaks placed on the middle of the sides of the body are broader and more continuous than the other spots; thus on one side the upper one is continuous from the shoulder to over the rump, whereas on the other side it is broken in several places. The series of spots on the middle of the back and sides of the belly are broken into numerous elongate spots of unequal length. The fore and hind legs and feet are marked with rings of roundish white spots.

The younger specimen just received very much agrees with the larger one received from Holland, but is of a blacker colour, being fresh; and it has nearly the same white streaks, but is destitute of the small spots between the streaks on the hinder parts of the sides. They both have the upper part of the headdestitute of spots, and the lower part, including the cheeks and throat, with a number of similar-sized round white spots.

I am inclined to believe that the spotting or stripes of the young Sumatran tapir is liable to variation, because I observe that, although they have a similar character, their distribution varies considerably on the two sides of the same specimen.

\section{The Habitat of Pelargopsis gigantea. By Dr. Adolf Bersinard Merer.}

On page 123 of the present volume of the ' $A$ unals' the habitat of Pelargopsis gigantea is stated as "Salok, Sulu Islands." It must be "Sulu, Sulu Islands," if the name be written after the German manner; and the neighbourhood of the town of Sulu is meant, on the island of Sulu, of the group of the Sulu Islands. The Spaniards always pronounce and write "Toló," the Dutch chiefly "Sólog" or 
"Sólok," the English "Sooloo," sometimes "Sulo" "Lc., the Germans chiefly "Sulu ;" and the name has been written in still half a dozen other ways. As the natives on the spot say "Sólog," with a soft "s," it may perhaps be recommended to write the word in this manner.

Vienna, April 4, 1874.

\section{Contributions towards the Natural History of the Termites. By Dr. Fritz Müller.}

In 1856 C. Lespès discovered that both the soldiers and the workers of Termes lucifugus of the Landes were represented by male and female individuals with incompletely developed sexual organs. This statement was received with some hesitation by certain naturalists, and especially by Hagen, who sought in vain for these organs in the soldiers of various species of Termes and Hodotermes. M. Fritz Miuller's observations have dispelled the apparent contradictions which rendered this question obseure, and they reveal to us new facts of the highest interest in the history of the Termites.

At first M. Fritz Müller was no more fortunate than Hagen in dissecting workers or soldiers belonging to several different groups of the genus Termes proper. But in the workers and soldiers of the genus Calotermes he found the organization indicated by Lespès; and he even ascertained that in the soldiers of this group the reproductive organs are much less atrophied than in those of Termes lucifugus, and they acquire nearly the same development as in the winged individuals.

In the soldiers of Calotermes canelloe scarcely any external sexual differences are to be found; the ventral plates of the abdomen in the male and female soldiers are constructed as in the winged males. The reproductive organs of the female soldiers are scarcely distinguishable from those of the winged females, except by their slightly smaller size and the absence of the seminal receptacle. The contents of the tubes present some differences when compared with what is seen in the females. The reproductive organs of the male soldiers are exactly like those of the winged males, the testes alone being a little more slender in form.

In Calotermes nodulosus and rugosus, Hagen, the male are at once distinguished from the female soldiers by the structure of the eighth ventral arch. In the small number of female soldiers of $C$. nodulosus that he has dissected, the author did not find well characterized ova filling the whole calibre of the ovarian tubes; but he saw them in nearly all the female soldiers of $C$. rugosus.

As regards the organization of the workers of Calotermes, M. Muiller can say nothing, for the very sufficient reason that in the five or six species of that genus which he has observed in Brazil there are no workers at all.

Two forms of nymph had often been observed in the colonies of Termites; but Lespes was the first to study and describe them carefully in Termes lucifugus. His " nymphs of the first form," larger than the workers and larvæ, are recognizable particularly by their 